$\stackrel{N / 2}{N}$

Global Journals Inc

int

GLOBAL JOURNAL OF MANAGEMENT AND BUSINESS RESEARCH: F

REAL ESTATE, EVENT AND TOURISM MANAGEMENT

Volume 20 Issue 2 Version 1.0 Year 2020

Type: Double Blind Peer Reviewed International Research Journal

\title{
The Impact of Covid 19 on Event Management Industry in India
}

\author{
By Mr. Anup M Gajjar \& Dr. Bhaveshkumar J Parmar
}

Sankalchand Patel University

Abstract- Event management is a dynamic territory combining conventional project management concepts with technological innovation. It requires constant up-gradation and uniqueness to organize successful events. Industries and brands usually go for events to provide interactive experiences to the customers and to gain popularity; Whereas the big-budget and big-scale events are organized to form an image of brand/product/organizations and reputation too. If we compare the Event Management Industry earlier (one or two decades ago) now then the Event Management Industry has evolved on a big scale. As per one report generally, corporate sector spends around $20 \%$ of its revenues on meetings, seminars, and other events. As per the ongoing trend, it's being seen that MICE and wedding planning is the emerging branch of event management in India.

This paper is an attempt to describe how Covid-19 (Corona Virus Disease -2019)- a global pandemic affects the Event Management Industry in India as Event Management plays a significant role in the socio-economic development of any country. It is one of the foremost sources to generate employment for urban as well as the rural public

Keywords: event management, covid-19, event management industry.

GJMBR-F Classification: JEL Code: L80

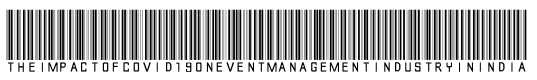

Strictly as per the compliance and regulations of:

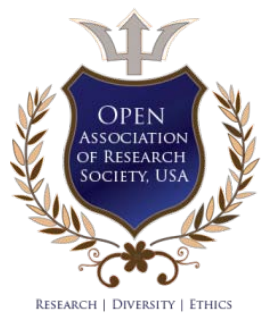

(C) 2020. Mr. Anup M Gajjar \& Dr. Bhaveshkumar J Parmar. This is a research/review paper, distributed under the terms of the Creative Commons Attribution-Noncommercial 3.0 Unported License http://creativecommons.org/licenses/by-nc/3.0/), permitting all non-commercial use, distribution, and reproduction in any medium, provided the original work is properly cited. 


\title{
The Impact of Covid 19 on Event Management Industry in India
}

\author{
Mr. Anup M Gajjar ${ }^{\alpha} \&$ Dr. Bhaveshkumar J Parmar ${ }^{\sigma}$
}

Abstract-Event management is a dynamic territory combining conventional project management concepts with technological innovation. It requires constant up-gradation and uniqueness to organize successful events. Industries and brands usually go for events to provide interactive experiences to the customers and to gain popularity; Whereas the big-budget and big-scale events are organized to form an image of brand/product/organizations and reputation too. If we compare the Event Management Industry earlier (one or two decades ago) now then the Event Management Industry has evolved on a big scale. As per one report generally, corporate sector spends around $20 \%$ of its revenues on meetings, seminars, and other events. As per the ongoing trend, it's being seen that MICE and wedding planning is the emerging branch of event management in India.

This paper is an attempt to describe how Covid-19 (Corona Virus Disease -2019)- a global pandemic affects the Event Management Industry in India as Event Management plays a significant role in the socio-economic development of any country. It is one of the foremost sources to generate employment for urban as well as the rural public.

Keywords: event management, covid-19, event management industry.

\section{InTRODUCTION}

T he Event Management industry has emerged as one of the fastest-growing sectors contributing significantly to Indian economic growth and development. In a globally preferred emerging destination for Event Management, India has significant potential to become one of them. Due to diverse cultural heritage, abundant natural resources, and biodiversity, it helps to gain the attraction of foreign travelers to organize the event and to visit the country.

In the past decade; The Indian event management industry underwent a dramatic change. Earlier it was considered as a business of managing wedding décor and catering, but Still, nowadays it has redefined and a business that takes care of every 'happening,' be it private or public. Now people want every occasion to be done on a big scale, hence individuals and Event organizations need to hire professionals to handle the events. Various Event companies offer vast services like managing, designing, execution, vendor management, product launches, etc. To manage private activities or public events or any

Author $\alpha$ : Research Scholar, Sankalchand Patel University, Visnagar, Gujarat, India. e-mail: anupgajjar@hotmail.com

Author 6: Associate Professor, Sankalchand Patel College of Engineering. Visnagar, Gujarat, India. e-mail: callbhavesh@gmail.com other special occasion, everything needs management. The event management sector in India is the fastest growing industry in India. To manage private activities or public events or any special occasion, everything needs management. "Social media" the emergence has significantly contributed to this sector. Many events such as large-scale the event, award shows, etc. easily gets highlighted not only in newspapers or T.V but also on multi-dimensional social media platforms through concern individuals.

If we take a look at the statistics, As far as the size of the event management industry is concerned; the Indian economy has witnessed remarkable growth. As per the expert's belief, It is just the commencement of a new era; as it has grown significantly. As per the report, it is expected that the industry will cross Rs 10,000 crore by $2020-21$ as per reports. In 2016-2017 the growth of the industry stood at Rs 5,631 crore and grew at 16\% CAGR (Compound Annual Growth Rate). Digital activation, Exhibitions, Trade shows, rural expansion, product launches, personal events, government initiatives, etc. can betaken into consideration to be the key growth drivers for the industry.

\section{Events classification}

It can be classified into Commercial Events and Non-Commercial Events mainly; however, it may be classified in various categories.

$\begin{array}{cl}\text { i. } & \text { Social events, } \\ \text { ii. } & \text { Corporate events, } \\ \text { iii. } & \text { Entertainment events, } \\ \text { iv. } & \text { Educational events, } \\ \text { v. } & \text { Exhibitions and } \\ \text { vi. } & \text { Fairs and special events for clients. }\end{array}$

Social events include wedding planning event, sundowners event, kitty parties for women, anniversaries, birthday parties celebration, flea market, fundraising events for charitable trusts for the special organization or non-commercial events, social gathering, get together, etc.

Corporate covers meetings, off-sites, team building activities, seminars, webinars, conferences, award functions, brainstorming, and annual picnics, etc.

Events like movie promotions, concerts, Sunburn music events, award nights, celebrity nights, DJ Nights, music/video album releases, etc. is 
considered in the entertainment events type. Educational events include science fairs, start-up meet, technical fests, college events, annual sports event etc.

Weddings are one of the emerging event categories and quite expensive in India nowadays. Prewedding photo shoot and video shoots are also getting acceptance in India widely. Wedding Planners are even using the most current or latest techniques (like drones, slo-mo, fast forward, emotions, etc.) to shoot promo videos, images in innovative ways. In India; Indian people spend an average amount of $\$ 31,213$ for his/her wedding, the result is as per the survey taken sometime back. The situation has changed nowadays, and anyone who has the willingness to spend finance in the event can have the wedding ritual of his/her dreams. The condition is also not far different when it comes to birthday parties and anniversary parties, corporate events.

\section{a) The economic aspect of Event Management}

The EEMA [Event and Entertainment Management Association] reveled a report in September 2017. Some of its crucial findings were, The Indian Events industry is expected to cross the 10,000- crore by Financial Year 2021. The record was based on organized events in the country, which is only $50 \%$ of the entire event industry. The figure is excluding induced revenues, direct benefits such as telecast rights. It had a value of 1 billion US dollars in FY 20172018. The report also states that it has been growing at the rate of a 16\% CAGR (Compound Annual Growth Rate) overpowering the Entertainment and Media industry growing at an $11-13 \%$ CAGR. In a few years, it is expected to grow at a rate of $20 \%$.

\section{b) Segment-wise revenue contribution}

Digital Events are one of the most widespread and are earning substantial returns for organizers nowadays. This is expected to contribute around $8 \%$ of the total industry revenue. Activations or Product Launches have the second-highest the potential at 22\%. The Managed Events sector has the potential to make $53 \%$ of the total revenue in the coming few years. Property shows account for only $2 \%$ of the total number of events. They contribute, including exhibitions $17 \%$ of the industry's total revenue. Mostly if we talk about the clients, then $75 \%$ of clients of event firms are from corporates, mainly $36 \%$ are Indian companies and, 19\% are from global or international. The Government Events and Public Sector Events contribute around 11\% of the total Industry Revenue. High Net Worth individuals contribute $9 \%$ and associations establish the remaining $5 \%$ clients.

\section{c) Latest trends in Event Management}

A mixed combination of the virtual and realworld is becoming continuous in today's events market. Modern technology makes it effortlessly available and affordable for the masses and the public. Artificial Intelligent has played a role from the time of conceptualization of any events until the organizers collect feedback or event finishes. Crowd finding is a standard today in concerts, flea markets, exhibitions, etc. Venues are no longer stadiums and fixed; People are expecting to have brainstorm activities in natural places rather than convention centers. Wedding events are taking place at the fort, forest, spiritual spaces, and no longer in party plot or banquets. Real-time data is being used for determining the form and development of events. Event safety is one of the importance of event organizers for any event.

\section{About Covid-19}

A novel corona virus is an infectious disease that has not been identified in humans ever before. Corona viruses (CoV) have an enormous family of viruses that spread between animals and people that most people who got infected with the COVID-19 viruses have experienced slight to modest respiratory illness and recovered without requiring special treatment in most cases. Commonly observed symptoms of COVID19 include fever, cough, shortness of breath, sore throat, and breathing difficulties. In more serious cases, the infection can results in pneumonia or severe acute respiratory syndrome, particularly in Old age people, and those who are suffering from or had agonised medical problems like heart problems, diabetes, any chronic respiratory disease, and cancer, etc. and even death.

Concerning public health globally, the World Health Organization (WHO) has declared the outbreak an health emergency on 30 January 2020 and documented it as a pandemic on 11 March 2020. As per the Health ministry's reports; till date (29 April 2020) more than 3.10 million cases of COVID-19 have been testified in more than 175 countries and territories, resulting in more than 2,10,000 deaths. More than 900,000; people have recovered, although there may be a possibility of relapse or reinfection.

The virus is mainly spreading between persons through close contact, often via minor droplets produced by sneezing, handshaking, talking or coughing. While these droplets are producing when breathing out, they ordinarily drop to the ground or onto clean surfaces rather than stay in the air over long distances. Individuals may also become infected by touching the unclean surfaces and then touching their nose, mouth, or eyes. The life of a virus is; it can live on surfaces for up to 72 hours or more.

The best way to stop spreading and to slow down the transmission is to provide adequate information to the people about the COVID-19 virus, the disease it causes, and how it spreads. To protect yourself and others around you from infection is to wash 
your hands often using soap and water/using an alcohol-based sanitizer, rub frequently and not touching your face. To maintain a safe distance from everyone who has symptoms of cough and sneezes, to cover your nose and mouth with handkerchief/tissue/mask, when you cough or sneeze, avoid unnecessary visits to the public or crowded area or medical facilities. to follow the directions of health care authority. Currently, there are no specific vaccines or medicines or treatments for COVID-19 are available, However, many laboratories and researchers are working on It, and a few have successfully started the trial on the animal. There are many clinics/hospitals doing primary treatment which is symptomatic therapy, and helpful in most cases.

Suggested defensive measures many countries have taken, which includes hand washing, covering one's mouth when coughing, maintaining social distance from other people around you, and monitoring and self-isolation for people who doubtful they are infected. Authorities worldwide have responded by implementing travel quarantines, workplace hazard controls, restrictions, curfews, and stay-at-home orders, and facility closures, sanitizing places.

The pandemic has produced severe global socioeconomic disturbance, including one of the biggest global recessions in history. It has triggered Event Organisers to rescheduling or canceling sports, political, religious, and cultural events. Schools, universities, colleges, and other educational institutes have closed either on a nationwide in 196 countries, affecting approximately 98.4 percent of the world's student population.

\section{a) Coronavirus-2019 pandemic in India}

In India; The first case of the coronavirus pandemic 2019 was reported on 30 January 2020. Till date (29th April 2020), the Ministry of Health and Family Welfare department of the Indian Government has confirmed a total of 31332 cases, 7695 recoveries and 1008 deaths in the country. As per the expert's review, the number of infectious cases could be much higher because the testing rate in India is low in the world. The infection rate of Coronavirus 2019 in India is testified to be 1.7, considerably lower than in the worst most affected countries.

More than $20+$ states of India and Union, Territories have confirmed positive cases of coronavirus; where provisions of the Epidemic Diseases Act 1897, has been invoked, and it results in the shutdown of businesses like; educational institutions, farming, fisheries, industries, and many commercial establishments etc. India has suspended all types of tourist visas, to prevent the spread of the virus. Indian Government started lifting the Indian nationals from different countries.

The Indian government stopped issuing new visas on $3^{\text {rd }}$ March 2020.
On 4 March 2020, Dr. Harsh Vardhan (Hon'ble Minister of Health and Family Welfare- India) announced an essential screening of all international passengers arriving at the airport from various airports in India. More than lakhs people have been screened at airports, borders, and many of them were under isolation and surveillance he mentioned.

On 13 March, the Government of India (Gol) closed all passenger traffic (airway, seaway, roadway, railway) from all neighboring countries. All visas were suspended, except for diplomatic and another official visa, the visa-free travel for Overseas Citizens of India too. All foreign travelers returning to India from COVIDaffected countries were asked to be compulsorily quarantined for 14 days. It helped to some extent spreading the COVID-19.

On 14 March, the union government stated the pandemic as a "notified disaster" under the Disaster Management Act, 2005, allowing states to devote a larger part of funds from the State Disaster Response Fund to fight the coronavirus and to save the lives of people.

On 19 March, Indian Prime Minister Narendra Modi appealed all to join for 'Janata Curfew' (people's curfew) from 7 am to 9 pm on 22 March during a 30minute nationwide live telecast. Through this curfew, he appealed everyone, except those involved in essential services, to stay at home.

On 24 March, A nationwide lockdown for 21 days has been imposed, which was ordered by the prime minister of India Narendra Modi; which directly affects the entire 1.3 billion population of India.

Michael Ryan, the chief executive director of the World Health Organisation (WHO)'s health emergencies program, said that India had "tremendous capacity" to treat with the coronavirus outbreak and, as the secondmost populous country, It will have a massive impact on the world's capacity to deal with it. Other reporters worried about the economic destruction caused by the lockdown, which has enormous special effects on daily wagers, informal workers, micro and small enterprises, farmers and the self-employed, who are left with no livelihood in the nonappearance of transportation and access to markets.

On 23 March, Coronavirus positive cases had been reported in some district hence union and state governments announced the lockdown of 75 districts. On 24 March, the Prime Minister of India declared a complete nationwide lockdown, starting from midnight for 21 days.

On 14 April, Considering the growth rate of the pandemic; PM Narendra Modi has overextended nationwide lockdown till 3 May, with a provisional relaxation from 20 April for the green zone area. A United Nations report projected a trade impact of US\$348 million on India due to the COVID-19 the outbreak, creating India one of the 15 worst affected 
economies across the world. India's economy is expected that the pandemic could cause losses of up to US\$29.9 billion as per the Asian Development Bank. The coronavirus lockdown in India left high chances of unemployment; considering that PM had to add, "Do not terminate any employees."

\section{Iil. EfFect of Covid -19 on Event Management Industry in India}

As per the Event and Entertainment Management Association (EEMA); All large scale events across all categories have been postponed or canceled due to coronavirus (COVID-19) outbreak and due to the nationwide lockdown which is expected to take a ₹1 trillion hit by Sanjoy K Roy, president of Event and Entertainment Management Association (EEMA).

This comprises both formal sector and informal sector, events and trade exhibitions, entertainment events (IIFA film awards, movie promotion, music concerts, stand-up comedy shows), Sports Events (T20 cricket tournament IPL, Football events, other private and government sports events), MICE and hospitality, food and beverages, wedding events, other social events.

Currently, It is difficult to calculate the exact loss. While shootings have been suspended and promotional events have been put on hold also television shooting gets postponed, it has also affected the release of new Bollywood-dholywood movies. Several National - International sports events have been either postponed or canceled, and this carries huge losses for the sports the industry as well. For instance, the cancellation of IPL matches alone could mean a loss of Rs 10,000 crore itself for the industry.

Joseph, co-founder, and director, Wiz craft International, said that major effect would be on Small and medium enterprises, as are high chances for them to wipe out as it would be very problematic for them to survive in the hard-hitting market the situation for long. From all the segments; hospitality sector, MICE (Meetings, Incentives, Conferences, and Exhibitions) have been hit the most due to several cancellation events across the country during this time as well as in the next few months too. Considering the impact on Travel, it directly affects foreign participation in events.

The size of an Indian Event Market is Rs. 10,000 crore; as per the Event and Entertainment Management Association (EEMA)'s the report. This excludes weddings, trade fairs, and exhibitions. If the latter is added, the overall market touches Rs 40,000 crore, said Sabbas Joseph. Now due to complete lockdown; all big scale events are being canceled or indefinitely postponed which means they are looking at $100 \%$ revenue loss as there are no chances of gathering public or crowd even National level exhibitions or trade shows have been postponed. While some event companies have adopted digital platforms but not all events can be planned, and online doesn't have a sustainable financial model, said Roy. Around 90\% of daily wagers and appx. Ten million jobs under the event industry is at stake.

Mr. Roy added that In this sector, due to lockdown. there is no incoming money in April month, and the venue which is carrying huge inventory, are also facing the heat. The payments which were pending for the government (state and central) events that have been completed; the body has also requested to release that at the earliest.

The Event and Entertainment Management Association (EEMA) is straight performing with Confederation of Indian Industry (CII) and Federation of Indian Chambers of Commerce and Industry (FICCI). EEMA has requested in written and urged the government to cover the cost of salaries of daily wagers, sops for the industry, tax refund, loan facilities for the MSME sector, workers, affected by COVID-19 pandemic, and they are unable to resume the work, statutory dues, and a moratorium of paybacks on loans, interest-free for a few months.

Globally impact and aid to the Event Industry; Germany announced $\$ 50$ billion into the art economy, Similarly; the United Kingdom has released 150 million pound in art segment, To Counter the impact of novel virus; Singapore, Dubai and Australia have also released funds on the events, exhibition, and creative arts industry In India; Unfortunately, in India, we can't map that How much creative arts sector contributes to the GDP of the country, as we don't come under one ministry or one department because for that, data is required, and without data, it would be very challenging to map the overall impact In this sector, Roy added.

\section{ReVIEW OF Literature}

\section{a) $K P M G(2020)$}

The pandemic novel coronavirus (COVID-19) has infected more than 150 countries and more than 28 lakh people in the world, The situation has now been aggravated by the demand, supply, and liquidity shocks that COVID 19 has imposed. Three scenarios have been explained to understand the economic effects,

1. Quick reaction across the globe including India by end April to May 2020; as china has started its manufacturing a sector where the first case has been identified; they expect GDP between 5.35.7percent for FY2020-2021.

2. While India can control COVID-19 spread, there is an important global recession- where India's integration with the global economy, in this case, India's growth will be lower and expected from 4-4.5 percent. 
3. I lockdown gets extended domestic and global demand will destruct and India's growth is expected to fall below 3 percent.

4. Mahendra Dev and Rajeswari Sengupta (2020)

The economy was already in a dangerous state before Covid-19 struckCovid-19 has posed an unparalleled challenge for India. With the lengthy nationwide lockdown, global economic disruption of supplydemand chains, the economy is possible to face a prolonged period of slowdown Given the large size of the population, the unwanted situation of the economy, specifically of the financial sector in the pre-COVID-19 period, and the economy's dependence on labor, daily wagers, lockdowns, and other social distancing measures would be immensely disruptive. Policymakers need to be prepared to scale up the response to diminish the impact of the shock on both the formal and informal divisions and cover the way for a V-shaped retrieval.

\section{b) $\mathrm{FICCl}(2020)$}

Federation of Indian Chambers of Commerce \& Industry has mentioned the in its March 2020 edition that; India's growth the level will be slow as compared to previous years, they have involved the impact of COVID19 on the Indian economy, Projections given by different credit giver firms like S\&P Global 5.2\%, Fitch Ratings $4.9 \%$, Moodys 5.4\%, OECD 5.1\%. Different sectoral impact and losses have also been covered, and the suggestions have also been made which shields the industry like; Aviation, Tourism-Hospitality, Medical, Capital Market, Ecommerce, MSME, Entertainment/ Events/ Sports.

Similarly, the International Monetary Fund projected a GDP growth of 1.9 percent for India in year 2020, as the global economy hits the worst recession since the Great Depression in the 1930s recently assessed by the World Bank.

\section{Sweety Jamgade (2018)}

In tourism, MICE tourism (Meetings, Incentives, Conference/Conventions, and Exhibitions/ Events) this niche tourism segment- MICE in India is booming nowadays. With the help of this paper, it is easy to found that the growth of MICE tourism in Bangalore is 21$40 \%$ overall. It has been found that multicultural cities of India like New Delhi, Bangalore, Mumbai, Cochin, Chennai, Hyderabad and Kolkata are the advanced business centers in the nation.

\section{C) Sustain your event Business amid COVID-19}

The events industry has been badly hit by the Coronavirus Pandemic. Most of the events are getting canceled or postponed, and it has been marked as the biggest crisis in the event industry evet.

It's a confusing situation for event organizer or event planner. On the one hand, they must follow the guidelines of public health officials and the directions of government to stop the spread of the COVID-19; on the other hand, they have to sustain their event business after lockdown gets over.

1) Safety of the event attendees

To make sure the attendees are very safe by providing them with safety kits- using sanitizers, sanitization of the venue, safe travel, taking a registration-travel history, on-call doctor, temperature measure, availability of the medical facility, food quality, service staff's safety and to follow the guidelines provided by the Government,

\section{2) Communication}

An Organizer should be responsible enough for adequate announcements and passing necessary information regarding the precautions to take before attending the event to all the participants/attendees via using different platforms like posting on social media, sending and emails, etc.

\section{3) Financial Planning}

In an uncertain time, it plays a vital role in maintaining regular cash flow. It is the fact that you can no longer organize events (only physical) in this period. To sustain your business long run, you should cut down or minimize your operational costs and marketing budget.

\section{4) Encouragement}

In this tough time, it does not mean you have to stop all of your business activities due to cancellation/Postponement of events. Work from Home is the concept that should be used at the most in this time, so the tasks should be defined in such a way that can be done remotely. Even after the market starts practically for the planning of an event can be done from home until and unless the physical meeting is required.

\section{5) Future Planning}

Using the lockdown period wisely, and instead of cribbing over the situation, you can make strategies for future events that are to be organized or can be organized. An Organizer should think about the different ideas and implement them in an effective manner to serve their customers/attendees. You can utilize the time wisely for idea generation or for creative ways that lead to survival in the future.

Considering Lockdown Event and Activation Industry had a webinar using the available software technology used. EEMA, EMF (Event Management Federation-Ahmedabad) had organized WEBINAR using ZOOM application to address the queries from all over India; let me summarise;

Advising clients to plan for possible scenarios, like keep up to date with the latest information -avoid fake news, take reasonable steps to increase hygiene standards. Once you have this in place you then Communication plays an important role - with your team 
and your audience, pre-event, during the event, and post-event.

If your core business is not events, but suppose you organize corporate events, conferences, staff parties, or let say MICE segment, the risks presented by Coronavirus essential to be considered up against the outcomes of the event. This is understandable, and clients or organizers will make decisions based on their situations.

- Stay current - To deploy someone from your team to understand the situation and to keep up to date with government advice and related information.

- Design - An important part of event management "Design" spaces to reduce crowd stupidities, create virtual participation opportunities as and when available.

- Communicate - Have a clear acceleration plan for how to deal with COVID-19 during events.

- Plan - To develop a strong action plan for finance from vendors to staff, and to support the short term fututre too.

- Make hand-washing more accessible. Warm running water, soap, and sanitized napkins should be readily available. Using social media messaging, physical signages, staff awareness, and communicating this message to attendees on arrival.

If we talk about the Wedding Event the biggest market in India; People may switch their wedding venues, or maybe big fat weddings have more impacts due to the fear of traveling, fear of gathering more people from different places. If a venue shifting option is feasible then, from scratch to final everything has to be reworked and rearranged i.e. decoration, Food and beverages, including flights, hotel accommodations, and local transportation.

\section{d) Research Methodology}

The main objective of this paper is to outline the impact of COVID-19 on the fastest-growing and emerging Industry of Event Management in India. Given the nature of the study, the most opportune approach was the documentary research, oriented in two directions: one, based on the observations and discussions of Event Management Professionals review - Online Webinar organized by various Event Management bodies and professionals like; Event and Entertainment Management Association of India (EEMA), Event Management Federation (EMF) the other one based on secondary data.

e) The Objective of the Study

The purpose of this section is to provide a critical overview of the impact of pandemic Coronavirus disease -2019 on Event Management \& Convention Industry in India.

\section{Conclusion}

Concluding remarks for the past $20+$ years, it has been acknowledged that Event \& The activation Industry has significantly increased exponentially. Weddings are a major business in India-can be considered under the social events was expected to \$40-50 billion in size; the second largest wedding market after the USA. It can be said that Event including MICE tourism is largely associated with business travel and is rapidly expanding all over in India, which was expected to cross Rs. 10000 crore by 2021. Which got tremendous hurdle and as per the Leading Association and Experts it is expected to take Rs. 1 Lakh trillion hit. But due to the Global pandemic novel, Corona Virus Disease 2019 has heavily affected the economy globally. Federation of Indian Chambers of Commerce \& Industry and international cooperative audit body has projected the growth of the Indian Economy as very low. Which directly or indirectly affect the Event Industry which is the biggest crisis the Event Industry is to be witnessed, to bring up the industry on up the Government, local bodies support is expected. The pandemic effect has left a strong impression on individuals' mindset in terms of travel fear, public gathering fear which will directly or indirectly affect the future of the Event Industry on an extensive scale; As event industry allies and working with and under different departments and bodies like Tourism, Transportation, Hospitality, Entertainment, Marketing, MICE, F\&B, etc. Hence it is not possible to identify the loss adequately.

\section{References Références Referencias}

1. FICCI (2020), Impact of Covid-19 on Indian Economy, India.

2. Gade J. and Ankathi (2016), R. Tourism Management Philosophies, Principles and Practices. Hyderabad, India: Zenon Academic Publishing, pp 402.

3. http://ficci.in/spdocument/23195/Impact-of-COVID-1 9-on-Indian-Economy-FICCI-2003.pdf

4. http://www.igidr.ac.in/pdf/publication/WP-2020-013. .pdf

5. http://www.msruas.ac.in/pdf files/Publications/MCJ ournals/August2018/Paper5.pdf

6. https://apps.who.int/iris/bitstream/handle/10665/331 773/ WHO-2019-nCoV-Adjusting_PH_measures2020.1-eng.pdf accessed April 2020)

7. https://economictimes.indiatimes.com/industry/med $\mathrm{ia} /$ entertainment/ive-events-industry-sustains-near-r s-3000-crorelosses/articleshow/74702552.cms?utm _source $=$ contentofinterest\&utm_medium $=$ text\&utm campaign $=$ cppst

8. https://economictimes.indiatimes.com/news/econo $\mathrm{my} /$ policy/pm-reviews-impact-of-covid-19-onecono 
my-2nd-stimulusinconsideration/articleshow/751810 12.cms?utm_source $=$ contentofinterest\&utm_mediu $\mathrm{m}=$ text\&utm_campaign $=$ cppst

9. https://eemaindia.com/

10. https://hire4event.com/blogs/future-of-event-manag ement-in-india/

11. https://tbinternet.ohchr.org/_layouts/15/treatybodyex ternalDownload.aspx?symbolno=E/C.12/2000/4\&La $\mathrm{ng}=\mathrm{en}$ (accessed April 2020);

12. https://www.bizencyclopedia.com/article/the-future-o of-the-indian-event-management-industry

13. https://www.eventmanagerblog.com/coronavirus-me etings

14. https://www.livemint.com/industry/media/coronaviru s-indian-events-and-exhibition-sector-to-take-rs-1-tri illion-hit-11585564755584.html

15. https://www.teami.org/overview-of-indian-event-man agementindustry/

16. https://www.who.int/emergencies/diseases/novelcor onavirus-2019/technical-guidance/infection-preventi onand-control (accessed April 2020)

http://www1.umn.edu/humanrts/instree/siracusaprin ciples. html (accessed April 2020)

17. https://www.who.int/publicationsdetail/critical-prepa redness-readiness-and-response-actionsfor-covid19 (accessed April 2020)

18. KPMG (2020), Potential Impact of Covid-19 on the Indian Economy

19. https://home.kpmg/content/dam/kpmg/in/pdf/2020/ 04/potential-impact-of-covid-19-on-the-Indianeconomy.pdf

20. Sweety Jamgade (2018) Scope of MICE Tourism as an Emerging Hospitality Industry, M.S.Ramaiah University of Applied Sciences, Bangalore.

21. Walker (2012), J. R. Exploring the Hospitality Industry. Harlow, England: Pearson Education Ltd, pp.300.

22. WHO. Ethics \& COVID-19 - Restrictive Measures and Social Distancing. March 2020. WHO. Ethics \& COVID-19-Restrictive Measures and Social Distancing. March 2020.

23. https://en.wikipedia.org/wiki/2020_coronavirus_pand emic_in_India

24. https://en.wikipedia.org/wiki/2019\%E2\%80\%9320_c oronavirus_pandemic

25. https://www.who.int/health-topics/coronavirus\#tab= tab 1

26. https://www.thedrum.com/opinion/2020/03/11/whatnew-with-coronavirus-and-what-can-event-organiser s-do-combat-it 